\title{
Much Appreciated? The Rise of the Canadian Dollar, 2002-2008
}

\author{
MICHAEL B. DEVEREUX \\ University of British Columbia and CEPR*
}

\begin{abstract}
Between 2002 and 2008, the Canadian dollar appreciated in real terms against the US dollar by 60 percent. This large change in real exchange rates between such major trading partners as Canada and the US is almost unprecedented. This paper explores the historical background to the movement of the Canadian dollar during this period, discusses the most accepted explanations for the appreciation, and speculates on the implications for the Canadian economy. The discussion is placed within the framework of recent developments in the theoretical and empirical literature on exchange rates.
\end{abstract}

Keywords: Canadian Dollar, Exchange Rates, Appreciation

JEL Classifications: F3,F4

\section{Introduction}

The Canadian dollar has been one of the most volatile of all world currencies in the past five years. At the beginning of 2002, the dollar was valued at 62 cents in US currency. At the end of 2007, the dollar was at almost exact parity with the US dollar. This represents a 60 percent appreciation over a five year period. Since inflation rates in the US and Canada are almost the same, there was an equal movement in the real exchange rate. In other words, average prices of goods and services in Canada increased by 60 percent, relative to those in the US, over this time. This is an unprecedented movement in relative prices for countries that trade so much with one another. In the past few decades, the international system has had large variation in exchange rates among major currencies. The fluctuations in the Japanese yen relative to the US dollar in the 1980's were greater than the recent movement in the Canadian

\footnotetext{
* This paper is based on a presentation prepared for the 2008 Mabel F. Timlin lecture, presented at the University of Saskatchewan, February 13, 2008. I express thanks to the Department of Economics at the University of Saskatchewan, and especially Bob Lucas, for hospitality. I also thank Max Chabym, Joel Bruneau, Bob Lucas, Gregor Smith, and audience participants for suggestions. Yao Tang provided excellent research assistance. Financial assistance from SSHRC, the Royal Bank, and the Bank of Canada is gratefully acknowledged. The views in this paper are those of the author and not those of the Bank of Canada.
}

(C) 2009 Michael B. Devereux. Licensed under the Creative Commons Attribution - Noncommercial 3.0 Licence (http://creativecommons.org/licenses/by-nc/3.0/. Available at http: //rofea.org. 
dollar. The euro appreciated by about 70 percent against the US dollar between 1999 and 2007. But Japan, the US and the euro area are very large economic areas, whose trade interdependence with the US, relative to the size of their economies, is relatively small. By contrast, Canada and the US have one of the largest trading relationships of any two countries in the world. The two countries are highly interdependent, with 80 percent of Canadian exports going to the US, and 65 percent of its imports coming from the US.

What accounts for the movement in the Canadian dollar over this time? How much of the currency movement is unique to the US and Canada, and how much is accounted for by a world decline in the US dollar? How is the currency appreciation likely to impact on the economy? Is it good or bad for economic activity? What actions, if any, should the Bank of Canada be taking to respond to the currency movement? Does the volatile dollar hinder the vital trading relationship between Canada and the US? Given that the two currencies are very close to parity at present, should the government of Canada consider taking steps to abandon currency independence altogether and, in light of the European example, consider a single North American currency union based on the US dollar?

This paper tries to make sense of the recent movements in the Canadian dollar. We address the above questions along a number of dimensions, using as our benchmark the basic macroeconomic theory of exchange rates. The exchange rate is the key relative price governing any country's interaction with the rest of the world. Yet exchange rates are highly variable, influenced by many factors, and are notoriously hard to predict. Interpreting trends in exchange rates is fraught with difficulties. Predicting future movements in exchange rates is almost impossible. But, given the central importance of the exchange rate in international trade and financial markets, it is vital to have an understanding of the fundamental forces that drive their movements. If the recent surge in the Canadian dollar can be understood as an equilibrium reaction to global forces impacting on the Canadian economy, then the central bank and the government should simply let the exchange rate take its course and refrain from intervening. On the other hand, if the dollar is simply a victim of short term speculative forces facilitated by volatile financial markets, then the excessive real exchange rate movements could impart long term damage to the economy, and countervailing policy may be required.

We begin by discussing the movement of the Canadian dollar over the path of recent history. While the recent surge in the currency is unprecedented, the dollar has experienced large swings in its value in the last 50 years, and the recent episode should be interpreted in light of this. We follow this by discussing the usefulness of exchange rate theory, and its ability to offer an analytical understanding of recent movements. While in general, exchange rate movements are extremely difficult to predict, and even to rationalize ex-post, the Canadian dollar has a more predictable pattern due to its relationship with commodity prices. We then offer a detailed analysis of the recent movement of the dollar. We argue that the size 


\section{DEVEREUX Much Appreciated? The Rise of the Canadian Dollar}

of the recent appreciation has to be decomposed into a global factor, arising from the general fall in the US dollar, and a Canada-specific factor, coming from forces impinging directly on the Canadian economy. We then present a discussion of the impacts of the recent rise in the dollar on the economy. How is the strong dollar likely to affect economic growth, inflation, and Canadian well-being? Finally, we discuss the implications of the recent movements in the currency for Canadian monetary policy.

\section{The Historical Movements of the Canadian Dollar}

How does the Canadian dollar's experience of the last few years compare with the historical movement of the dollar? While the recent currency appreciation has indeed been unprecedented, we should not lose sight of the fact that the dollar has had very substantial fluctuations in value over the past 30 or 40 years. Figure 1 charts the annual progress of the currency since 1949. Behind the figure lies a fascinating series of separate historical episodes.

Figure 1: Historical Trajectory of Canadian Dollar Exchange Rate

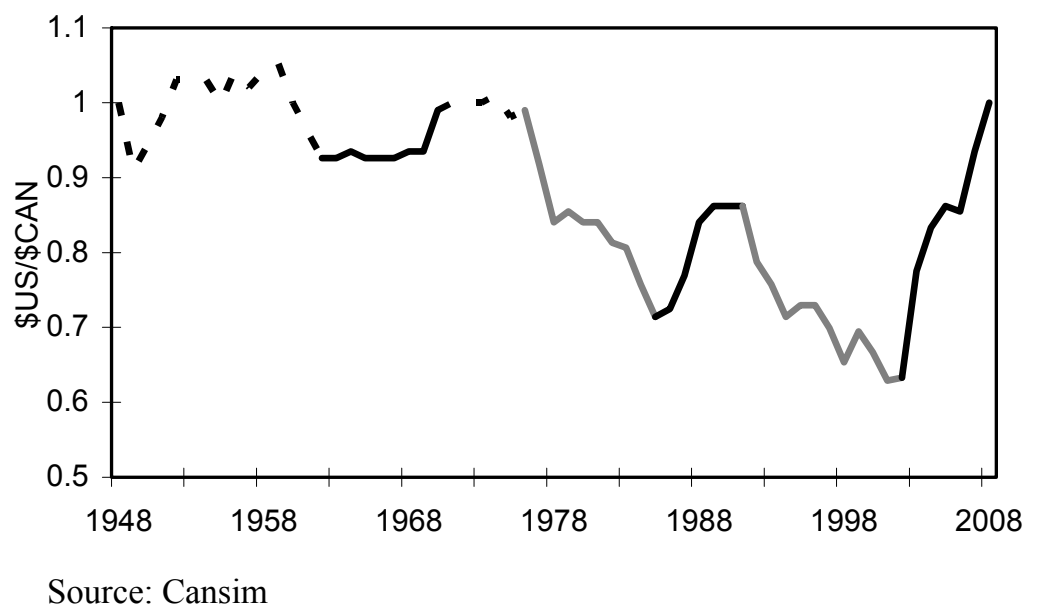

Economics undergraduate students are usually taught about the history of the international monetary system beginning from the post WWII period based on a simple narrative. In the immediate aftermath of the Second World War, the Bretton Woods system of international currency arrangements required all countries to set fixed exchange rate parities against the US dollar. This then is seen as a long period of fixed exchange rates, which only ended in 1971 when the US de-linked its currency to gold, and the major industrial countries allowed their currencies to freely float. This is essentially an accurate description of the evolution of international monetary arrangements between 1948 and 1971, with one exception. Canada 
did not fix its exchange rate during the 1950's. In fact, taking an unprecedented and much criticized action, Canada floated its currency in 1949, and allowed the value of the dollar to be freely determined on foreign exchange markets for the next 11 years. What led to this decision? The records from the time indicate that there was strong upward pressure on the Canadian dollar due to inward capital flows in the late 1940's ${ }^{1}$. To avoid this, the Bank of Canada would have had to reduce interest rates, and this raised the danger of increasing inflationary pressures. In this situation, the Bank of Canada decided that floating was the best option.

This intellectual background that supported the Bank's decision was contained in Friedman's classic defence of flexible exchange rates, which was refined and later published in 1953. His argument goes as follows. When a country such as Canada receives a macroeconomic 'shock' from the outside world (a classic one would be an increase in the demand for its export commodities) then adjustment must involve a change in the relative price of its exports, or terms of trade. With a positive shock, requiring the terms of trade must improve. One way to achieve this would be to increase the Canadian dollar price of export goods. But this would entail substantial domestic inflation, and if prices are slow to adjust, may lead to overheating in the domestic economy. An alternative mechanism for achieving terms of trade appreciation would be for the country's currency to increase in value. Since this does not involve any change in domestic prices, it is not inflationary, and causes less internal disruption in goods and factor markets. Friedman's analogy was daylight savings time. It is better to move all clocks forward by an hour in spring, rather than requiring each household to individually adjust their daily routines up by an hour. This is the equivalent of moving the country's real export price by changing the exchange rate, rather than letting individual prices setters adjust Canadian dollar price of all export goods. In this sense, the exchange rate plays a vital role in the adjustment process after an economy is hit by external shocks. It acts as a way to facilitate relative price adjustment in a smooth and painless fashion.

If all movements in the historical US-Canadian exchange rate could be simply decomposed into the response to measured fundamental shocks, then Friedman's analogy would be perfect, and would represent a strong case for allowing the exchange rate to adjust freely without policy intervention. As we see below however, the actual experience of the Canadian dollar has been a lot more complicated.

Figure 1 illustrates the bilateral US Canada rate from 1948 to 2007, expressed in terms of the popular convention; US dollars per Canadian dollar. The first thing to note is that there has been a lot of variation in the currency over this long period, much of it involving a weakening dollar. But surprisingly, we have ended up almost exactly where we started - with

${ }^{1}$ For a recent account of the Canadian experience with flexible exchange rates, see Bordo and Dib and Schembri (2007). 


\section{DEVEREUX Much Appreciated? The Rise of the Canadian Dollar}

the Canadian and US dollar very close to parity. We will later discuss one of the central theories of exchange rates - the 'Purchasing Power Parity' (PPP) theory, and we will see that, in the long run, this theory has some quite well supported predictions ${ }^{2}$.

The movement of the Canadian dollar since the WWII is a story in seven chapters. The first chapter comprises the 1950's, during which the dollar floated against the US dollar, as discussed above. During the 1950's the Canadian dollar was quite strong - above parity most of the time. It peaked in July 1957 at 1.06 US. But at the end of the decade, the Canadian economy slowed, as the long resource-driven investment boom of the 1950's abated, and the currency weakened. The Canadian experiment with floating ended in 1962 when the Bank of Canada re-entered Bretton Woods, the international fixed parity agreement, at a value of 92.5 US cents. During the rest of the 1960's, the currency was pegged at this rate. But the multilateral currency stability that Bretton Woods had brought to the international monetary system was fast dwindling as the 1960's progressed. There was a widespread erosion of confidence in the fixed peg between the US dollar and gold, the lynchpin of the Bretton Woods system. Inflation was becoming a worldwide concern, and European governments believed that the Bretton Woods system 'exported' US inflation to Europe. In Canada, the fall in US dollar confidence was putting upward pressure on the currency, requiring the Bank of Canada to continually intervene in order to prevent appreciation. In 1970, the Canadian dollar was again allowed to float freely, and has done so ever since (by 1973, most other major countries were also floating against one another). The seventies, the third of our chapters of the trajectory for the Canadian dollar, were not unlike the very recent experience. World oil prices surged upwards after 1973, and the Canadian economy outperformed the US, at least for the early part of the decade. The Canadian dollar was strong - at or above parity up to 1976. But after the Quebec election of 1976, with increased political uncertainty, there was a sharp drop in the currency. This begins the fourth chapter in the dollar's history - a long, gradual weakening between 1976 and 1985. During the first half of the 1980's, the dollar lost 13 cents against the US dollar, bottoming out at 71 cents in late 1985. This episode coincided with Ronald Reagan's first term in office, in which the US dollar surged against all world currencies. The early 1980's US dollar bubble ended in late 1985 after the famous 'Plaza Agreement', in which the major world countries pledged to work towards a weaker US dollar and a reduction of the US current account deficit. Following this, the Canadian dollar began a slow but vigorous period of strengthening. This fifth chapter in the progress of the currency shows the typical rollercoaster pattern that is seen in earlier episodes. The currency appreciated slowly but persistently, peaking at 89 cents US in November 1991. This strong dollar period is quite a controversial part of recent Canadian policy history - it coincided with

\footnotetext{
${ }^{2}$ PPP's implications are for the real exchange rate. But because Canadian and US inflation experience has been so close, Figure 1 would look very similar if we used the real rather than the nominal exchange rate.
} 
the beginning of Canadian 'inflation targeting'. The Bank of Canada raised interest rates significantly and announced that it would thereafter follow a policy towards a significantly low and stable rate of inflation. The policy achieved considerable success in reducing Canadian inflation, but at least in the short term, the real economy performed very poorly. Canada slipped into a recession in 1990; this was a 'made in Canada' recession, since the US and other countries were still growing.

From 1992 onwards, the economy began to recover slowly, and the dollar started again on a long slow period of weakening. The currency was subject to multiple influences during this time; fiscal and political uncertainty during the mid 1990s, followed by global shocks and the series of world financial crises in the late 1990s. The lingering effects of the 1990-1991 recession, the Federal and Provincial budget deficit problems, and the Quebec referendum of 1995, lead to a progressive weakening of the currency up to the late 1990's. These effects had been staunched considerably by 1997, but then the international system was hit by the Asian financial crisis. Sudden collapse in Asian currencies and cutoff of capital flows to their economies led to a fall in world commodity prices, representing a big negative shock to the Canadian dollar. The overall picture from 1991 to 2002 shows a tremendous weakening of the currency, falling from 89 cents US in 1991 to an all time low of 61 cents US in 2002. At this time, which is really not very long ago, we began to hear talk of the 'long term decline' of the Canadian dollar. Newspaper reports and some economists began to speculate on the benefits of adopting the US currency.

But the long term decline of the Canadian dollar turned out to be itself illusory. In fact, as we will argue later, there were very good reasons to believe that the dollar was greatly undervalued in 2002. Moreover, for different reasons, there were strong reasons to predict a more general fall in the US dollar. This opens up our seventh and final chapter in the story of the Canadian dollar; - the dramatic appreciation of 2002 to 2007. In terms of drama, this clearly outshines any of our earlier episodes, for it contains the loonies lowest value in history, on January 21, 2002, at 61.79 US cents, and also its highest point in history, on November 7, 2007, a mere five years later, at 1.103 US cents, representing a 79 percent increase in value. It is this period that we will examine in much greater detail below.

\section{Exchange Rate Theory}

The exchange rate matters only in so far as it influences relative prices of goods and assets across countries. One key relative price is the real exchange rate. This is the price-adjusted value of the nominal exchange rate. The theory of purchasing power parity says that the real exchange rate should be constant, and equal to unity. Purchasing power parity says that the exchange rate should move to a level such that the price of a basket of goods in one country is equal to that of its trading partners. Another way to say this is that movements in exchange rates should reflect differential inflation rates across countries. 


\section{DEVEREUX Much Appreciated? The Rise of the Canadian Dollar}

Purchasing power parity theory has almost zero explanatory power for understanding exchange rates at high frequency. Figure 2 illustrates the real and nominal exchange rate for Canada from 1980 until the present. In addition, the Figure illustrates the ratio of price levels between the US and Canada. If PPP held, then the nominal exchange rate (blue line) should move exactly in line with the relative price level (green line). We see clearly that this is not the case. The nominal and real exchange rate move in tandem, and there is hardly any correlation between the nominal exchange rate and relative prices. When we compare the US and Canada, two countries with low and stable inflation rates, we find that relative price levels move only very, very slowly. In this Figure, Canada had a worse inflation performance than the US for most of the 1980's, so that US price level fell gradually relative to Canada. This was turned around after 1990 when Canada switched to an inflation targeting monetary policy, so the Canadian inflation rate fell below that of the US. But even allowing for these differences in inflation performance, we see the relative national price levels have moved little, and when they move do so very slowly. By contrast, nominal and real exchange rates are highly volatile, and move quickly.

Figure 2: Nominal and Real Exchange Rates

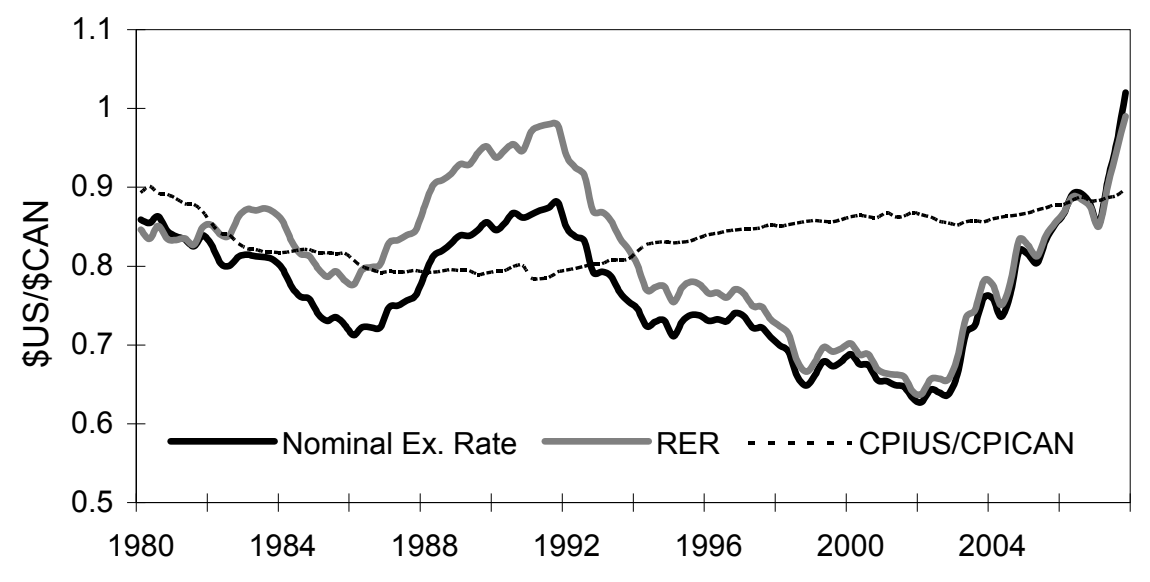

Source: Cansim

There is nothing very surprising in this. If PPP was true, then no-one would discuss the exchange rate, since it would really only be a way of converting between currencies, but it would not affect economic decision making. Nevertheless, PPP is a useful concept, because there is some evidence that it does tend to hold in the long run, even though it clearly doesn't hold in the short run. In the long run, if the exchange rate moves very far away from PPP, it tends to move back to its PPP level, although the time it takes for this reversion is hard to predict. Figure 3 illustrates this by introducing two definitions of the Canadian exchange rate. 
The first is the 'theoretical' exchange rate that would ensure PPP. This is measured and published by the OECD at annual frequencies. The chart indicates that the theoretical exchange rate, or PPP, started in 1980 at 86.5 US cents, and fell gradually to 83 cents in 2006. By contrast, the actual exchange rate was much more volatile, as we have already discussed in Figure 1. But nevertheless, it seems apparent from the Figure that the actual exchange rate has a tendency to return to PPP over time. Right now, it is clear that the Canadian dollar is above its PPP rate. Based on this chart, we may speculate that the future of the dollar suggests a fall.

Figure 3: PPP Exchange Rate and Actual Exchange Rate

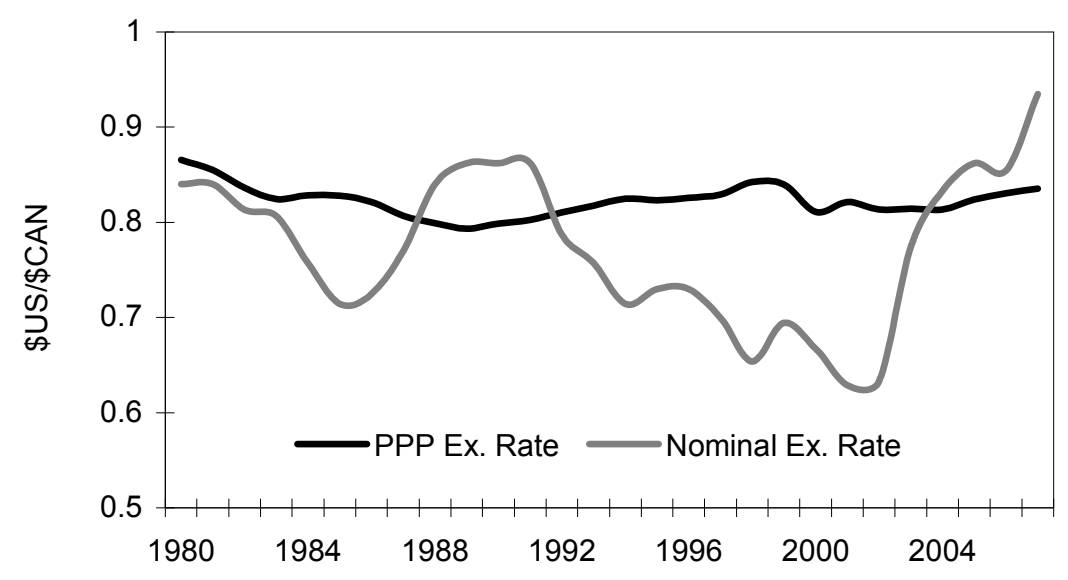

Source: IFS

But PPP is a weak theory of the exchange rate, and holds only in the very long run at best. There are strong economic reasons for PPP not to hold in the short run. PPP is based loosely on the idea that open economies must have very similar prices of goods, when evaluated in a common currency. If this did not hold, the argument goes, then competition would drive the prices toward equality. But we know that this type of ideal competition does not apply in practice. First, many goods are not in fact traded across countries - and so there is no clear reason for their prices to be equalized. A classic example is haircuts. It is not clear what competitive forces would be set in motion by having haircuts in Calgary more expensive than those in Denver, when evaluated in Canadian dollars. But this same attribute applies to many goods and services produced in both the US and Canada. What this means is that the real exchange rate may move away from PPP over time for good economic reasons.

PPP is not really a theory of exchange rates so much as a simple (and unrealistic) restriction on the relationship between the nominal exchange rates and prices. Once we 


\section{DEVEREUX Much Appreciated? The Rise of the Canadian Dollar}

realize that a complete theory of exchange rates must encompass the determination of the real exchange rate, then we must acknowledge the fact that there is no simple one-directional model of exchange rate determination - the exchange rate is determined by a whole host of macroeconomic influences simultaneously with other macro variables such as interest rates, stock prices, consumption, investment and GDP. The exchange rate is determined in a general equilibrium environment, in combination with other major macroeconomic variables.

This general equilibrium perspective on exchange rate and macroeconomic equilibrium lies behind the structural models that are used at the Bank of Canada and most other modern Central Banks in the world today. The underlying logic of these models extends the traditional 'Mundell-Fleming' model into a dynamic, stochastic general equilibrium (DSGE) environment, where the economy is subjected to internal and external shocks, in an environment of free international financial flows.

In the modern DSGE environment, the exchange rate is seen as a key part of the overall macroeconomic adjustment mechanism. Take for instance, an open economy that is hit by a negative shock to world demand for its goods. This will reduce the trade surplus, and lead to a compensating exchange rate depreciation. The exchange rate acts so as to 'cushion' the economy from the full impacts of the economic shock, since the depreciation in itself helps to stimulate net exports and partially offset the initial rise in aggregate demand.

A key feature of this model is that the exchange rate is not an exogenous force in itself, but is determined endogenously as part of overall macroeconomic equilibrium. Usually, in the long run, these models predict that the real exchange rate is consistent with PPP, in the short and medium run, the exchange rate is part of the overall macro adjustment process. In fact the role of the exchange rate in the macroeconomic adjustment process is an important element of the overall Canadian monetary policy agenda, as discussed below.

The basic theory behind such models has been developed and extensively revised over the last couple of decades. How is the theory supported empirically? Here, we find relatively discouraging news. Economists studying exchange rates have long come to grips with the findings that, while in the long run, the trend path of exchange rates are approximately consistent with economic theory, the behaviour of the exchange rate in the short to medium run is much more difficult to explain, statistically. The key problem is that, like stock prices, the exchange rate is an asset price. It is determined in financial markets, and financial markets tend to produce highly volatile prices. While over the medium to long run, we can understand the movement of the exchange rate using underlying economic theory, in the short run, the exchange rate is highly unpredictable.

These findings have been known for many years. Meese and Rogoff (1983), using only ten years of data on floating exchange rates among major currencies, found that no structural model of the exchange rate could statistically forecast exchange rate movements better than a random walk model. Given that the random walk model predicts that the future exchange rate 
is the same as the current exchange rate, this was taken as a general failure of economic models of exchange rates. A large subsequent literature has not much succeeded in reversing these findings. While studies have shown that at longer horizons, exchange rate models do forecast better than a random walk (e.g. Mark, 1995), it has remained very difficult to obtain strong empirical support for structural exchange rate models at the 1-2 year horizon.

Recent authors have argued however that the unpredictability of exchange rates cannot be necessarily be interpreted as a failure of exchange rate theory. As we have noted, the exchange rate is an asset price. As such, it will be influenced not just by current fundamentals, such as monetary policy, productivity, etc, but also by the expectation of future fundamentals. The exchange rate will move in response to changes in the economy's forecast for future fundamentals. In most models of asset pricing, it is likely that the weight placed on expected future fundamentals is substantially greater than that on current fundamentals. In an important recent paper, Engel, West and Mark (2008) show that as the weight on future expected fundamentals rises, the behaviour of the exchange rate should theoretically approach that of a random walk process. That is, even if fundamentals are predictable, and the exchange rate is determined by fundamentals, the exchange rate itself may be unpredictable. In essence, a random walk process for the exchange rate may be fully consistent with efficient financial markets where expectations of future fundamentals are of critical importance.

One key property of theoretical models of exchange rates is that the exchange rate plays the role of an asset price. That is, the exchange rate is the relative price of currencies, and as such should be determined in financial markets. Prices in financial markets are forward looking, and should reflect information about both current and expected future values of all 'fundamentals'. Engel West and Mark (2008) show that this implies that exchange rates should contain some predictability for future fundamentals. That is, movements in exchange rates should be able to forecast movements in future fundamentals. Here, they find some success. Even though the exchange rate behaves as a random walk in the data, innovations in exchange rates contain some predictive power for standard fundamentals such as GDP and money supplies.

It is not surprising that financial markets have a large role to play in the movements of the exchange rate. Traditional theories of the exchange rate are based around the role of trade flows; imports and exports of goods and services, in balance of payments and exchange rate determination. But the volume of international financial flows across national borders is almost a hundred times larger than trade flows. The Bank for International Settlements calculates the average daily volume of foreign exchange transactions at three year intervals. The past decade has shown explosive growth in foreign exchange trading volume. The most recent report estimated that the average daily world foreign exchange trading for April, 2007 was is 3.2 trillion US dollars, or an annual volume of 832 trillion, based on a 250 day year for financial markets. By contrast, the total volume of world trade for all of 2006 was 


\section{DEVEREUX Much Appreciated? The Rise of the Canadian Dollar}

approximately 12 trillion dollars. This represents only 1.4 percent of the annual world foreign exchange trading volume! Hence, it may not be surprising that at short horizons, movements in exchange rates seem quite disconnected from the real economy.

It is not just the direction of movements in the exchange rate that is hard to explain based on economic theory, but also the magnitude. The recent surge in the Canadian dollar represents a huge relative price change, applied to a whole economy. But movements in real exchange rates of this magnitude are not uncommon - in fact they are the norm. If we look at all OECD economies which exhibit a range of very different macroeconomic characteristics we find that the volatility of the real exchange rate is greater than that of GDP. In some cases, such as Japan, real effective exchange rate volatility is 5 times that of GDP.

It is tempting to conclude from this that exchange rates are excessively volatile, and that this excess volatility must have economic costs. Many writers have argued that exchange rate volatility must reduce international trade. The euro area was developed partly on the argument that stable real exchange rates were an essential ingredient in fostering trade flows within the EU. But, surprisingly, evidence for the costs of exchange rate volatility is very hard to obtain. It is not true that countries with more volatile real exchange rates have smaller trade volume than countries with stable exchange rates. Japan is a key example of a large open economy with very high real exchange rate volatility, but with a spectacularly successful export sector. The problem in developing the argument that exchange rate volatility is costly for international trade is that the exchange rate is not an exogenous price in itself, but is determined endogenously. Movements in exchange rates that represent responses to internal or external shocks may just as easily enhance international trade rather than detract from it.

There is a further sense in which exchange rate volatility is disconnected from the real economy. Popular discussion tends to imply that exchange rate movements are quickly passed through to imported goods prices. Thus, an appreciation should be reflected in lower prices of imported goods, and a depreciation should increase the price of imports. This relative price mechanism is central to the standard textbook model of exchange rate movements. But in fact, evidence for many countries has established that the degree of exchange rate pass-through into goods prices is very limited. Even for a small and open economy like Canada, the correlation between exchange rate changes and goods prices facing consumers is very low. As we will see below, very large fluctuations in exchange rates may have relatively minor changes in the price structure of traded goods that consumers actually face.

Most of the research on exchange rate economics has focused on the exchange rates of large country currencies, such as the US dollar, the Japanese yen, or the euro (and previously the German d-mark and other pre-euro European currencies). As discussed above, it has proven quite difficult to develop robust models which satisfactorily explain the behaviour of these exchange rates, at least at high frequencies. For these currencies, exchange rates seem 
disconnected from fundamentals. But there is another group of countries for which movements in exchange rates are some better explained. These are countries with a large share of resources or primary commodities in their exports. Among OECD economies, Australia, Canada, New Zealand, and Norway are examples of these currencies. For these currencies, the data show that a substantial fraction of exchange rate volatility is linked to movements in commodity prices. These are called 'commodity currencies', for obvious reasons.

Figure 4 illustrates this phenomenon for Canada. Figure 4 shows the real effective exchange rate, alongside the 'traditional fundamentals' which appear as principle determinants of exchange rates in the basic theoretical models. In particular, the Figure includes a) movements in relative Canadian-to US GDP, and b) movements in the Canada-US interest rate differential. It is apparent from the Figure that there is little correlation between the real exchange rate and these measures of traditional exchange rate fundamentals. This is not surprising, given our discussion on the lack of empirical support for traditional exchange rate models. But for the commodity currencies, there is a much more robust relationship between commodity prices and exchange rates. Figure 5 shows the relationship between two measures of commodity prices and the real effective exchange rate. One index measures commodity prices generally, and the other index contains commodity prices excluding energy prices. It is clear that, for both indices, there is a correlation between commodity prices and real exchange rates. It is not a perfect relationship, but in general, the Figures imply that a rise in commodity prices is generally associated with a real effective exchange rate appreciation. In fact, the relationship seems to have become tighter over the past two years. The rise of the Canadian dollar since 2002 is quite closely tied with the run-up in commodity prices.

Figure 4: Canadian Dollar and Traditional Fundamentals, 1980Q1=100

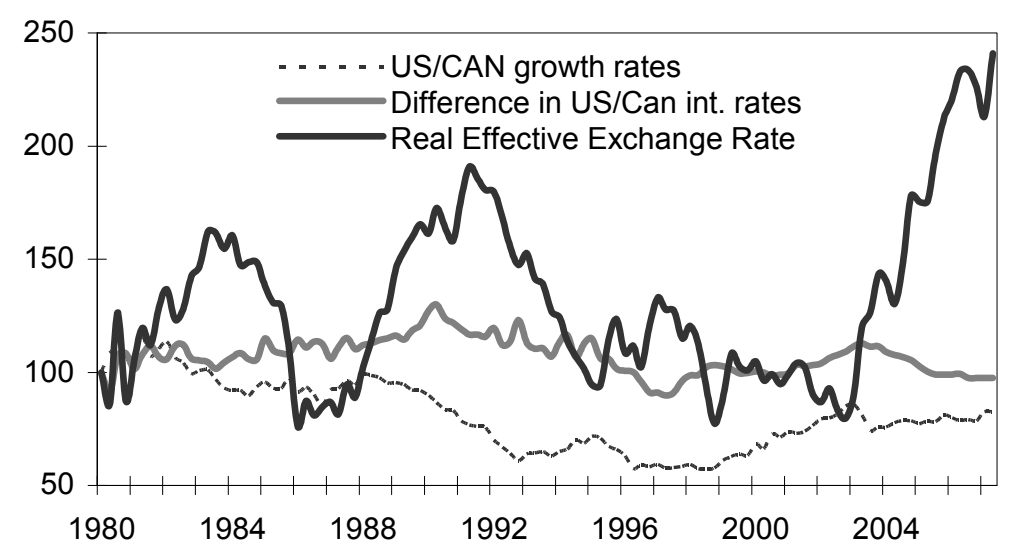

Source: IFS 


\section{DEVEREUX Much Appreciated? The Rise of the Canadian Dollar}

This relationship between commodity prices and exchange rates for a number of commodity exporters has been established more formally in the empirical literature on exchange rates (e.g. Amano and Van Norden, 1993, Chen and Rogoff 2003). Indeed, commodity prices form a central part of the understanding of the recent dollar movements. The Bank of Canada maintains a forecasting model for the dollar in which this link acts as a key mechanism driving the real exchange rate (Murray 2007). To the extent that commodity prices drive the real exchange rate, the Bank can use the estimated relationship to assess the degree to which the Canadian dollar may be 'undervalued' or 'overvalued'. We will discuss the Bank's exchange rate model further in the next section.

Figure 5: Canadian Dollar and Commodity Prices, 1980Q1=100

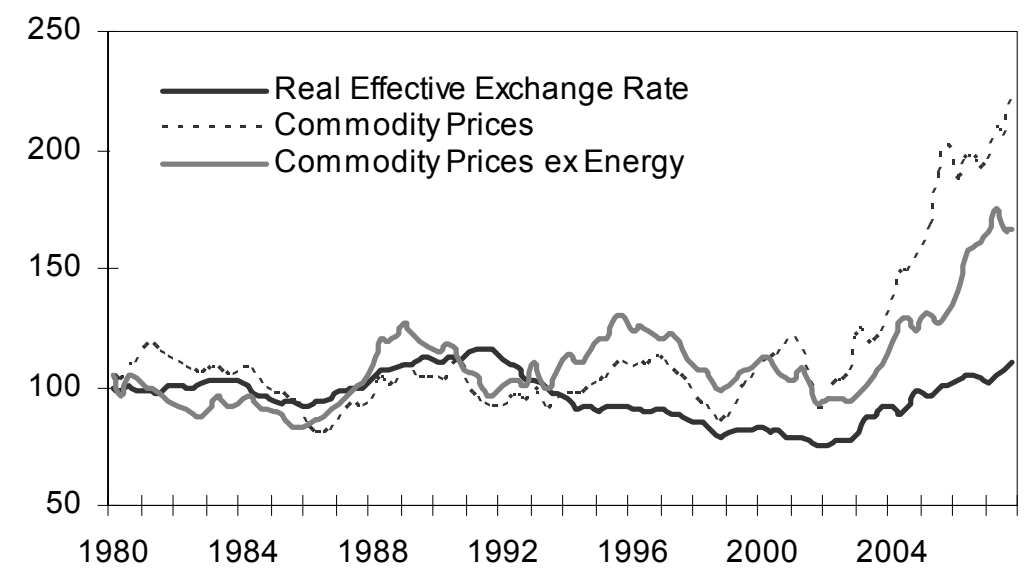

Source: Cansim, IFS

\section{The Canadian Dollar 2002-2008}

In this section we provide an analysis of the recent movement in the Canadian dollar, from the perspective of the theoretical models of exchange rates discussed in the previous section. We argue that an adequate discussion of this episode must allow for two quite separate influences over the exchange rate. The first reflects the general multilateral decline of the US dollar, which can be accounted for mainly by US specific forces, quite independent of Canadian events. The second group of factors represents Canada specific events, relating to the strength of the Canadian economy, the Canadian fiscal position, and most importantly Canada's position as a net commodity exporter in a time of a worldwide commodity boom.

To get some sense of how important each of these two factors is in the movement of the bilateral Canada US exchange rate, we focus on Figure 6. This describes the fall of the US dollar relative to all world currencies (the real effective exchange rate), and the fall in the 
bilateral US dollar exchange rate against the Canadian dollar. Measured in this way, the US real effective exchange rate fell by 17 percent, while the bilateral real exchange rate against the Canadian dollar fell by 30 percent. Hence, in this simple accounting exercise, just over half the movement in the Canadian dollar may be attributed to global factors influencing the US dollar, and half to Canada-specific factors. We discuss these two factors in turn.

Figure 6: How Much of the Rise in the Dollar is Canada Specific? 1980Q1=100

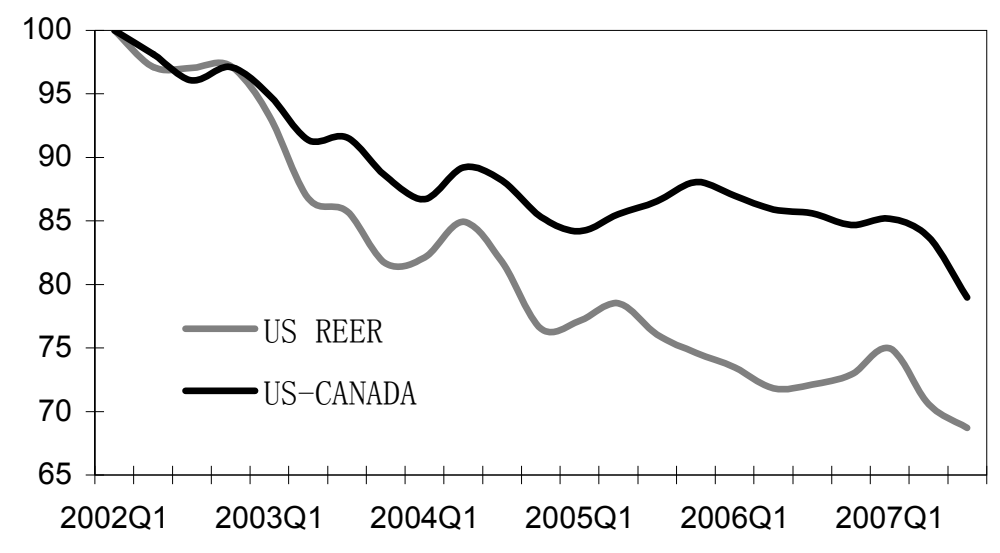

Source: IFS

\section{Global Influences on the US dollar}

It has been apparent to most observers for some time that the US dollar was likely to experience a considerable real effective depreciation. The principle force behind this is the size and persistence of the US current account deficit. The US has experienced a current account deficit for the last 15 years, but the deficit, measured relative to GDP - (see Figure 7), was quite manageable up until 2000. After this however, the current account deficit began to rise rapidly, reaching 6.5 percent of GDP in 2006. There has been a debate on the causes of the current account deficit. On the one hand, the proximate cause can be seen as a fall in the US saving rate from the mid-1990's onwards. But the counterpart of the US current account deficit is a current account surplus in the rest of the world. Since the euro area has had an approximate current account balance, essentially all of this surplus has come from emerging market economies, mostly Asian economies, and more recently, the oil exporting economies. In East Asian economies, investment rates fell substantially after the Asian crisis of the late 1990's, leading to increase trade surpluses. In China, for many reasons, there has been a significant increase in savings rates, and savings has also increased substantially in the oil exporting countries as consumption has not caught up with the increased windfall income from the run-up in oil prices. 


\section{DEVEREUX Much Appreciated? The Rise of the Canadian Dollar}

Figure 7: The US Current Account as \% of GDP

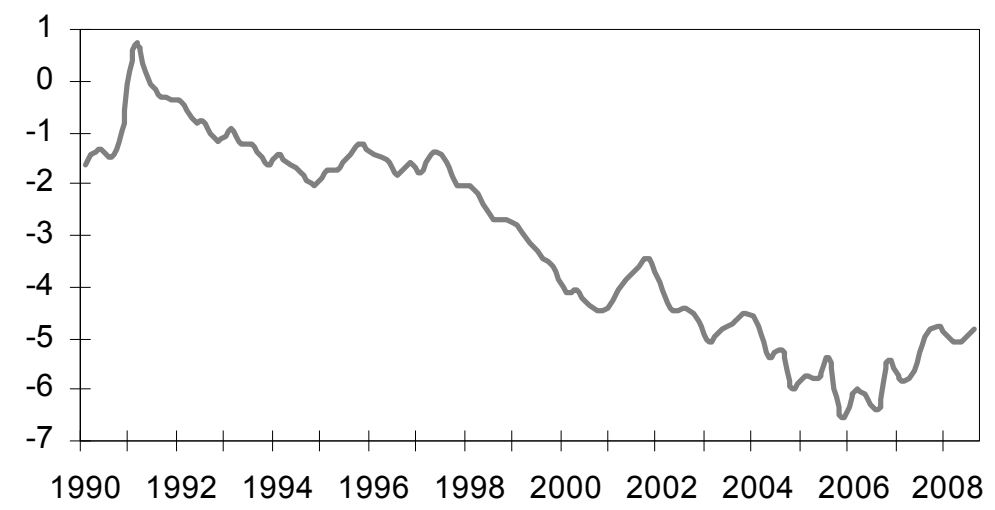

Source: BEA

Traditional economic theory would predict capital flows from wealthy advanced economies to poor growing economies. The recent experience has been the exact opposite of this. Can such as situation be efficient, and sustainable? One perspective sees the US deficit as being driven by inefficiently low US savings, which must be reversed in order to maintain a sustainable external debt position. Another view sees the central cause as an excess of savings in emerging market economies and oil exporters. In addition, it is argued that many of these economies have an absence of stable, safe investment prospects, and prefer the relative safety of US assets.

Whatever the cause of global imbalances, the consensus view among economists is that US current account deficits of over 6 percent of GDP are unsustainable, since it must result in a rapid buildup in US net foreign debt - estimates based on projected growth of the US lead to net debt to GDP ratios of over 100 percent. This would not only place an unacceptable burden on the US economy in order to service this debt, but runs the risk of a collapse in international confidence in US assets and a sudden cutoff of the US from an ability to borrow on international markets.

If the US deficit is to fall, then almost any economic model would predict that a real depreciation of the US dollar is required. Traditional net export driven models of the current account would argue this based on the necessity of increasing export competitiveness and reducing total imports. But even from a more macro savings-investment viewpoint, a turnaround in the current account should require a shifting of resources out of non-traded goods and into the traded goods sector, and a fall in overall expenditure relative to income for the US economy. This reallocation in expenditure would inevitably generate a real exchange rate depreciation.

There have been a variety of estimates of the extent of the real depreciation in the US 
dollar that would be associated with a current account stabilization. Obstfeld and Rogoff (2005) argued that a current account rebalancing would be associated with a thirty percent real depreciation of the US dollar. At the time, this was seen as excessively alarmist. Many economists argued that adjustment could be effected with a much smaller change in exchange rates. But as we've seen, the Obstfeld and Rogoff number was not an overestimate, as the fall in the real exchange rate from the peak in 2002 has in fact been approximately 30 percent.

Has the fall in the dollar helped to turn around the US current account? Figure 7 shows that in fact the current account deficit has started to diminish, starting in late 2006. But it remains at a much higher level than is thought to be sustainable. There are a number of reasons that the impact on the current account has been small. First, there is a natural delay between movements in real exchange rates and movements in the trade balance. Economists have christened this the 'J-curve effect', suggesting that a real depreciation may initially be associated with an amplification of a current account deficit before the deficit shrinks and moves toward surplus.

Aside from this conventional effect however, there are two specific issues related to the US situation which may explain why the turnaround in the current account has been so slow and muted. The first is that the US dollar has experienced significant real depreciation, it has not depreciated against many of the countries against which it experiencing large current account deficits. This is particularly true of the US China case. China followed a pegged nominal exchange rate against the US dollar until late 2006, and since then has allowed for some nominal appreciation, but much less than might be expected if the Renminbi was freely floating. At the same time, the Chinese overall current account surplus has grown tremendously in the last 3 years, and was approaching 12 percent of GDP for 2007 . The real appreciation of the Renminbi against the US dollar has been far less than the overall real effective depreciation of the dollar. Most of the US dollar adjustment has taken place against the euro, the UK pound, the Canadian dollar, and the Australian dollar. But these are not countries with an unusually large trade surplus with the US. Hence, the 'right' form of exchange rate adjustment has not been experienced, and at the same time, it has been argued that the freely floating currencies have had to endure excessive appreciation of their currencies against the dollar. According to this 'spillover theory', the rise of the Canadian dollar (as well as the euro and the UK pound) has been excessive, precisely because the truly undervalued currencies, such as the Renminbi, have been kept fixed.

Another non-standard potential explanation for the lack of response of the US trade balance to the real depreciation lies in the direct impact of currency movements on net foreign assets. For the US, almost all the US gross liabilities are denominated in US dollars - for instance, a lot of US dollar treasury bills are held as official reserve assets by foreign central banks. On the other hand, most US gross assets are denominated in euro and other non-dollar currencies. An example is FDI and portfolio equity assets held in Europe and other areas. As 


\section{DEVEREUX Much Appreciated? The Rise of the Canadian Dollar}

first noted by Tille (2005), this means that an unanticipated nominal depreciation of the US dollar automatically reduces the net external debt of the US, since it increases the dollar value of gross assets relative to gross liabilities. Take for instance, the situation where the US has all its assets in euro, equal to about 60 percent of GDP (approximately the case empirically), while it has all its liabilities in dollars, approximately 90 percent of GDP, leading to a thirty percent of GDP net foreign debt. For a given nominal GDP, a nominal depreciation of 10 percent will raise the value of assets to 66 percent of GDP, reducing the size of net foreign liabilities to 24 percent of GDP. The upshot is that, for given external asset and liability composition, pure valuation effects can achieve substantial adjustment in the US net external position, without any corresponding movement in the trade balance. This idea has been pursued at length in Gourinchas and Rey (2007).

\section{Canada-Specific Influences on the Canada-US Exchange Rate}

While there have undoubtedly been substantial global pressures on the US dollar, there have also been clear forces specific to Canada leading to pressure for an appreciating currency. As we saw in section 1, the Canadian dollar was deeply undervalued in 2002, on a purchasing power parity basis. Based on this consideration alone, one might have predicted a strengthening of the currency. Of course we acknowledged that PPP is a very weak and imperfect benchmark on which to predict currency movements. But all the other macroeconomic factors that should influence real exchange rates also led to the conclusion that the Canadian dollar would appreciate. In particular, Canada had a very strong trade and current account surplus - exports had been booming since the late 1990's. In general a trade surplus should be associated with an appreciating real exchange rate. Also, as a result of the fiscal stabilization of the mid 1990's, Canada had a unique position in terms of the government budget. In contrast to the US, and most other OECD economies, Canada was in a robust structural fiscal surplus. With the recession of 2001, many countries had seen their fiscal positions weaken considerably. Hence, all the usual indicators pointed to an improvement in the currency. But what was not foreseen at all is the extent of the increase in the dollar's value. Most forecasters at in 2003 and 2004 were predicting a rise in the loonie to the mid 80 cents US. As we've seen, this is approximately the PPP level. But we know that the exchange rate surged past this prediction at the end of 2005, was up close to 90 cents by end 2006, and then broke through parity by late 2007 .

What accounts for the magnitude of the appreciation of the dollar? The clear culprit is the world price of oil. In fact, using the Bank of Canada exchange rate equation, this statement can be supported quantitatively. But before we do this, it is instructive to look at some trends in Canada's export patterns. Figure 8 decomposes Canadian exports into different product categories, expressed as a share of total exports. First, two of the major traditional export sectors; machinery and equipment, and auto products, have been losing export share since the 
late 1990's. Indeed, autos have been cut almost in half, as a share of exports. Secondly, the share of forestry products has been falling sharply since the same time. But the most dramatic piece of the figure is the spectacular rise in the share of energy products in total exports. From 1999 to 2007 the share of energy in exports almost triples - going from 7 percent to 20 percent. In fact, the growth from 2002-2007 is almost the same magnitude. Hence, it is clear that energy, and especially oil, has become much more important, and this has come at the expense of some traditional export sectors. It is thus not surprising that the Canadian dollar has become more sensitive to oil prices. In fact, as noted in (Maeir and De Pratto 2007), the correlation between the dollar and energy prices has increased significantly since 2002, a fact suggested also by Figure 5 Hence, to a great extent, the rise of the dollar over the last 5 years can be tied to the price of oil.. This also comes out in the latest simulations of the Bank of Canada's exchange rate equation, which relies heavily on commodity and energy prices in its tracking ability.

Figure 8: Share in Canadian Exports

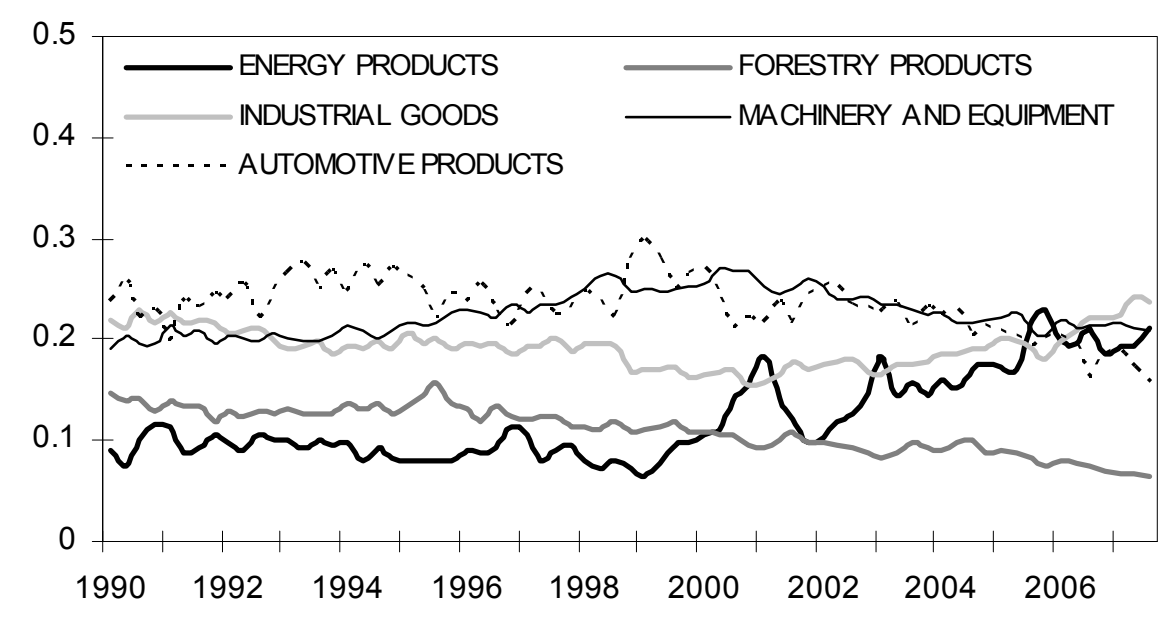

Source: Cansim

It is important to note however, that this type of reasoning, based on simulations of estimated equations, is a statistical definition alone. In the absence of a clear analytical modeling background (which we don't have), it is really not possible to be precise about the degree to which the currency is undervalued or overvalued. In fact, there is always a sense in which, if we are attempting to interpret the time path of asset prices, such as exchange rates, then it is very difficult to separate expectations from fundamentals. An example is given in Bachetta and Van Wincoop (2004). They explore a model in which exchange rates are determined by trading activities of a large group of differentially informed market participants. In this case, agents must attempt to predict not just the market fundamentals, but also the expectations of others. In this case, it can transpire that traders may end up focusing 


\section{DEVEREUX Much Appreciated? The Rise of the Canadian Dollar}

on a single public signal (such as the price of oil), because they correctly believe that other traders will form their expectations based on this same signal, even though this signal may have little or no fundamental structural relationship with the value of the asset itself. Essentially, in the environment of differentially informed traders, were agents are attempting a forecast of the forecast of others, beliefs can take on a life of their own. Thus, it is possible that the Canadian dollar becomes an oil currency in recent financial markets just because most foreign exchange traders are focusing on the price of oil in the decisions about buying or selling the dollar. That financial markets have a large role to play, at least in the short term volatility of the currency, is quite clear. The evidence, discussed in the previous section, and to which we return in the following section, is that financial markets tend to give rise to exchange rate overshooting. Thus, it is not necessarily legitimate to conclude that the linkage from oil price movements to the exchange rate supports the view that the movement of the exchange rate is efficient.

\section{The Exchange Rate and the Economy}

What impact will the recent real exchange rate appreciation have on the Canadian economy? In the popular press, there is a range of viewpoints. On the one hand, consumers may benefit from the opportunity for lucrative cross-border shopping. But exporters, especially those in the manufacturing sector, may find their profitability drastically eroded by the fall in the value of the US dollar. At the same time, manufacturers may find it profitable to engage in upgrading machinery and equipment at lower import costs, thereby improving productivity. Clearly, the impact of currency movements on the real economy is complicated and multidimensional. But it should always be kept in mind that the analysis of the link between the exchange rate and the economy cannot be done in a coherent way without an understanding of what drives the exchange rate itself. The exchange rate is not moving in a vacuum, but is responding in response to the underlying economic environment.

In this section we present a number of perspectives on how the exchange rate interacts with the behaviour of the real economy, and assess how the recent movements in the exchange rate may be interpreted. We begin by comparing the recent appreciation with the experience of 1990-1992, another era in which the currency experienced dramatic appreciation. As economists will recall, this also presaged a recession in Canada, followed by a period of low growth and very poor economic performance. Can we rule out a similar outcome this time?

\section{Will the Dollar Hurt the Economy?}

The recent media coverage of the strength of the dollar has been dominated by the prospect of job losses and the erosion of competitiveness in the export sector. Without doubt, the nature 
of a flexible exchange rate implies that certain sectors will be hurt by exchange rate adjustment. But the more pertinent question is whether the movement in the currency itself is a negative shock to the overall economy. To throw light on this question, we compare two episodes of major currency appreciation. The first dates back to the late 1980s and early 1990's. The Canadian dollar was extremely weak, relative to the US dollar in the mid 1980's, falling to its then lowest point in history of 69 cents US in February 1986. But five years later, the dollar had risen to 89 US cents. But the difference then, relative to now, is that the dollar reached a peak at a time when the Canadian economy was going into a sharp recession, which was prolonged for much of the early 1990's. Figures 9 and 10 compare the experience of 1988-1993 with that of 2002-2007. In both cases, the Canadian dollar was rising strongly over a period of years. But there were significant differences in the rest of the economy. In the earlier period, the trade balance was negative, and economy was barely growing. In the later period, there were large and continued trade surpluses, and robust growth rates. Why was the dollar rising in both periods? As we've seen in the discussion in the last section, commodity prices have played a large role in the recent movement in the currency. By contrast, in 1988-1992, commodity prices were flat, and actually fell from 1990 onwards. But the currency kept rising until late 1991. How can we account for the sharp appreciation of 1988-91, when the situation seemed so different relative to the recent episode?

The key difference seems to be related to the stance of monetary policy. In 1990-1991, the Bank of Canada followed a very tight monetary policy, as part of the inception of their inflation targeting policy. During 1990s, the Bank of Canada rate was 4.5 percentage points higher, on average, than the US Federal Funds rate. By contrast, in the last five years, there was almost no difference in the Canadian and US short term interest rates, as shown in Figure 10. On the surface, the strong currency in the early 1990's seems to be attributable to a very restrictive monetary policy, while the recent appreciation is more an episode of strong economic growth and high commodity prices. In the earlier period, as we would expect from a restrictive monetary policy, the appreciation was associated with a weak trade balance and slow growth, while in the later period, the booming economy itself drove the appreciation. In both episodes, we had an appreciating currency. But in the first, the currency rose because of high interest rates, which slowed the economy. In the second case, the combination of strong domestic demand and rising commodity prices stimulated economic growth and the value of the dollar at the same time. This helps to make the point that not all currency appreciations are alike ${ }^{3}$.

\footnotetext{
${ }^{3}$ It should be noted also that the fiscal situation in the late 1980's was quite different from the recent past. The Federal and Provincial governments had large budget deficits, and there was widespread concern about uncontrolled growth in government spending and debt. At least part of the interest rate differential between Canada and the US might be attributed to a ‘fiscal risk premium'.
} 
DEVEREUX Much Appreciated? The Rise of the Canadian Dollar

Figure 9: Exchange Rate and the Economy, 1988-1993

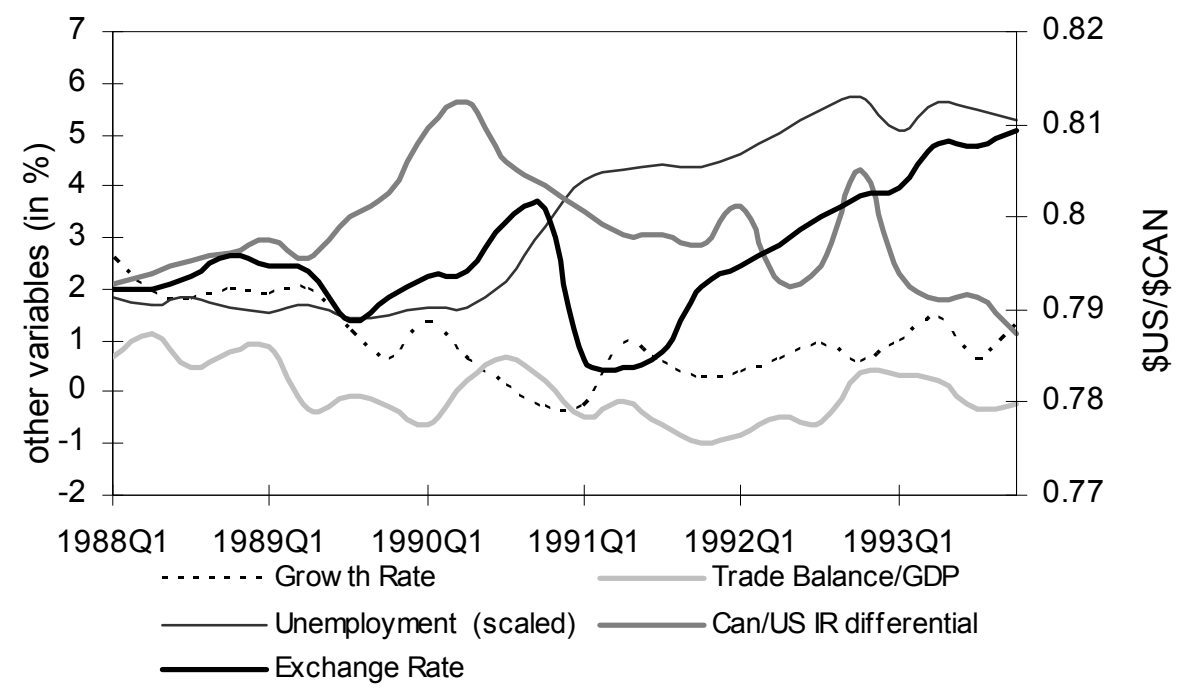

Source: Cansim, IFS. The unemployment rate has been scaled to fit in the figure.

Figure 10: The Exchange Rate and the Economy: 2002-2007

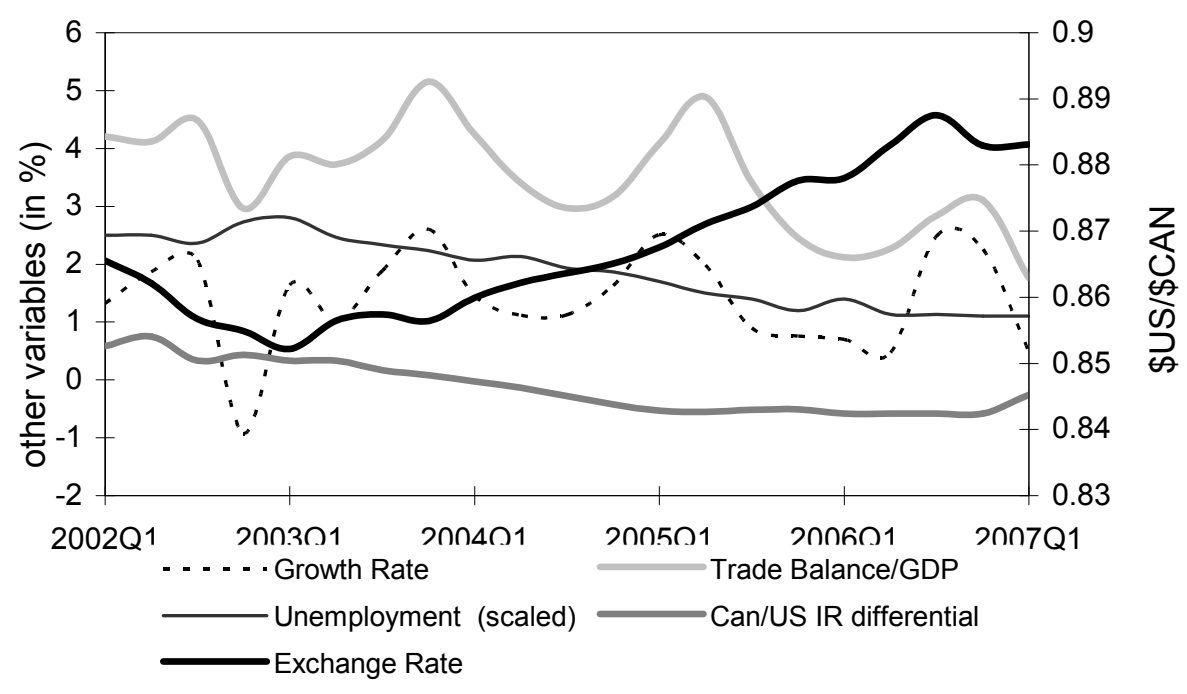

Source: Cansim, IFS. The unemployment rate has been scaled to fit in the figure.

\section{Dutch Disease Effects}

This is not to say that the present strong dollar is without problems. A real appreciation that is driven by domestic demand and commodity prices will inevitably have negative spillovers on traditional export sectors. This is clearly showing up in manufacturing export data, as 
we've seen in the previous section. At the time of writing, overall employment has held up, but employment in traditional manufacturing export sectors has been hurt badly. This raises the question of providing government assistance to the worst hit sectors. But this seems inappropriate, if the economy itself is still growing. It is only to be expected that economic growth will be associated with some growing sectors and some declining sectors. In an open economy, this process takes place partly through real exchange rate movements and changes in competitiveness. If there is to be a case for assisting sectors in decline, we should be able to identify some failure of the market mechanism to facilitate the process of adjustment to changes in sectoral or regional growth rates.

In fact, there is a large literature precisely on this question. The discussion is usually focused on the phenomenon of high growth and real appreciation associated with resource or commodity booms. The problem of macroeconomic adjustment to a resource boom has become known as the 'Dutch Disease'. The name comes from the Netherlands in the 1960's, when North Sea oil discoveries led to the appreciation of the guilder, which hurt the traditional exporting industries. Very similar episodes have been identified in the UK in the late 1970's, and more recently in Norway.

Does the Dutch Disease establish a case for government intervention? Does it have implications for exchange rate policy? This is a difficult question for traditional macroeconomics. In the usual macroeconomic policy problem, there is a case for loosening monetary policy if the economy is in a recession - i.e. if output is below potential. But in the case of a resource driven boom, driving up the real exchange rate, the economy as a whole may be at or above its potential. So it is hard to make the case for a relaxation of monetary policy to prevent the exchange rate rising, since this would only exacerbate the boom. Fiscal policy is a more useful instrument, if it is targeted at certain sectors being hit more directly by the real appreciation. But if goods and factor markets are behaving efficiently, it is in general difficult to argue that governments should intervene to prevent the necessary adjustment of the real economy. What circumstances would warrant such an intervention? One key consideration is that resource driven booms are likely to be a temporary phenomenon; the resource itself becomes depleted, or the increase in resource prices is reversed. In this case, job losses in traditional export sectors may be costly if they lead to scrapped capital that must be replaced when the resource boom ends. A recent paper by Caballero and Lorenzoni (2007) analyzes the impact of real appreciations in such an environment. They argue that, if the export sector is limited by financial constraints that lead to wasted capital, then there is a case for government subsidies. The case for subsidies is tied to the phenomenon of overshooting. If export sectors shut down and capital is wasted, the initial real appreciation will be followed by an excessive real depreciation once the resource boom ends. In this case, it is desirable for government to intervene both to limit the initial real appreciation and the subsequent real depreciation. But this intervention is done via taxes and fiscal policy. They do not explicitly 


\section{DEVEREUX Much Appreciated? The Rise of the Canadian Dollar}

make the case for monetary policy intervention. Whether monetary policy should be concerned with 'Dutch disease' affects is a difficult question. We will discuss this in the next section, where we focus on Canada's exchange rate policy.

\section{Exchange Rate Pass-through and Border Effects}

When there are large movements in exchange rates, the conventional economic model assumes that this will lead to adjustments in the costs of imported goods. For instance, if the Canadian dollar strengthens relative to the US dollar, the textbook model predicts that this would reduce the price of goods imported from the US. The degree to which movements in exchange rates are reflected in prices of goods is known as the 'exchange rate pass-through'. After the sharp appreciation of the Canadian dollar in late 2007, it was apparent that passthrough was far from perfect. Prices of many consumer items from books to cars remained much more expensive in Canada relative to the US. Because the rise in the Canadian dollar was so sudden and so large, after a long period of a weak dollar, this discrepancy in relative prices became quite widely recognized. But in fact, the very slow degree of exchange rate pass-through into goods prices has long been recognized in the economics literature (Mussa 1986). Changes in exchange rates tend to cause almost equal changes in relative prices of goods, and these changes in relative prices tend to be very persistent. This is just the micro version of the stylized fact we discussed in section 1 - where we noted that movements in the nominal and real exchange rates were very similar, except in the long run.

To see the effect of slow exchange rate pass-through, take the following example. Say we have four locations in North America, Vancouver, Los Angeles, Toronto, and Chicago. In the era of globalization and free trade, we are accustomed to thinking of North America as being a highly integrated economy. In particular, for locations that are relatively close to one another, like Los Angeles and Vancouver, or Toronto and Chicago, we might imagine that there is considerable trade, and we would anticipate trade to tend to equalize prices. On the other hand, for locations that are further away, such as Vancouver and Toronto, or Los Angeles and Chicago, perhaps prices would not be so close to one another. If North America were a seamless integrated economic union, then we should not expect that price comparisons between locations should be affected at all by the presence of the US-Canadian border.

It turns out however, that when we compare prices across locations, the border matters a tremendous amount - it is in fact the most important determinant of relative prices. This has been noted by Engel and Rogers (1996) and many other writers. To see this, let us look at Figure 11. There, we illustrate the movements in relative prices of city pairs during the 19901997 period. The pairs we focus on are Vancouver-Toronto, Toronto-Chicago, and Los Angeles-Chicago. Again, if all that mattered in determining price differentials was distance, then we would anticipate that the Vancouver-Toronto or the Los Angeles-Chicago price would be more variable than the Toronto-Chicago price. What do we see? We see exactly 
the opposite of this. The relative price level in Vancouver to Toronto tends to move very little over this period, and the relative price of Los Angeles to Chicago tends to move very little. But the relative price of Toronto-Chicago tends to move a lot. In fact, the price falls from 1998 onwards, until 2002, and then rises quite suddenly. So obviously the border makes a big difference in terms of relative price variability. Why is this? Well, the most obvious answer is the movement in the nominal exchange rate. If we look at the final locus on the Figure - movement in the Canadian-US dollar, we see that the relative price of Toronto-Chicago tracks almost perfectly the movement in the nominal exchange rate.

Figure 11: Relative City Prices and the Exchange Rate, January 1998=1

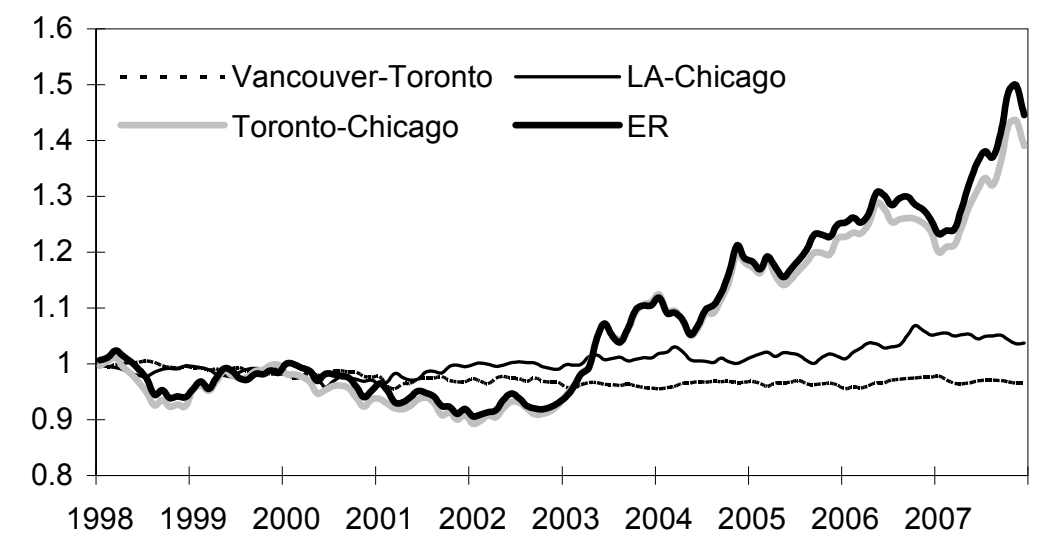

Source: BLS, Cansim

The data then suggest a very small degree of exchange rate pass-through. Movements in the exchange rate tend to generate equal movements in relative prices, because the actual dollar prices of goods on either side of the border do not tend to move very much. That is, over the course of this period, the price level in Toronto and Chicago was rising by about two percent per year, and didn't adjust very much to the wide movements in the Canadian US dollar exchange rate. The same conclusion may be drawn from the Vancouver and Los Angeles prices. The reason the border matters is that the two markets on either side of the border are using different currencies, and the relative price of these currencies - the exchange rate, is changing substantially. Exchange rate pass-through is limited - the evidence suggests that highly persistent movements in exchange rates tend to generate highly persistent movements in the relative prices of goods across borders.

What is the reason for such limited pass-through? This has been an area of intense research interest over the last decade. On the one hand, it is fairly widely acknowledged that nominal prices are slow to adjust in response to macro shocks, and if prices are set in domestic currencies, then exchange rate movements will cause fluctuations in relative prices 


\section{DEVEREUX Much Appreciated? The Rise of the Canadian Dollar}

across countries - even in goods that are traded. But empirical evidence (e.g. Bils and Klenow 2005) suggests that nominal price stickiness is quite a transitory phenomenon; most firms adjust their prices within a year at most. On the other hand, there is substantial evidence of persistence in real exchange rates and deviations from the law of one price (Rogoff 1997, Engel 1999). How can this be reconciled with short term price stickiness? A number of possibilities have been explored in the literature. One explanation is that in fact, pass-through at the imported good level is high, but measured prices of consumer goods contain a substantial 'non-traded' component in the form of local distribution costs. Another complementary explanation is that foreign exporting firms are in competition with local firms for the local market in many products - when the exchange rate depreciates, it increases local currency costs for these exporters, but competitive pressures prevent them from passing these directly through to the local markets, and they are forced to adjust their markups.

The full explanation of persistence in deviations in prices of traded goods across countries and the relationship between exchange rate fluctuations and such deviations promises to be a continuing area of interest.

\section{The Dollar and the External Wealth of Canada}

One little discussed effect of the stronger dollar is the effect on Canada's financial portfolio. On the factors behind US dollar weaknesses, we noted the impact of exchange rates on the US portfolio. Here we focus on the equivalent issue for Canada. Just as individuals and corporations have financial balance sheets that are separated into assets and liabilities, countries as a whole have external balance sheets. In this external balance sheet, the asset category is defined as the sum of all financial claims of Canadian individuals, corporations and governments on the rest of the world. For instance, this would include holdings of foreign corporate and government bonds, FDI holdings in the US, Europe, and elsewhere, as well as equity holdings in foreign country stock markets. Much of these asset holdings might be held indirectly by Canadian banks or pension funds, rather than directly by individuals. In the liability side of the external balance sheet, we would include foreign holdings of bonds issued by Canadian governments and corporations, FDI holdings in Canada, and holdings of Canadian stocks and shares held abroad. The difference between (gross) assets and liabilities give Canada's net foreign assets. The largest component of Canada's external assets is in direct investment abroad, while the largest component of its liabilities is in portfolio investment. Both aggregates are very large - in 2006, total assets were 71 percent of GDP, while liabilities were 77 percent of GDP.

In traditional balance of payments theory, we model the growth in net foreign assets as originating from trade or current account surpluses. If a country is experiencing a trade surplus, it will be building up claims on the rest of the world, and its net foreign assets will be rising. But when we acknowledge the portfolio structure of gross external assets and 
liabilities, we find that net foreign assets can be changed by movements in exchange rates or interest rates, even without any changes in the trade balance. That is, because gross assets and liabilities generally differ in their composition in terms of currency composition, maturity structure, and type of investment (e.g. bonds vs. stocks, etc), changes in exchange rates, interest rates, and security prices can actually change an economy's net foreign assets. Thus, an economy can experience fluctuations in its net wealth due to 'valuation' effects on its gross external portfolio.

How important can these valuation effects be? This depends critically on how large are gross external assets or liabilities, and their decomposition into different classes of assets. For instance, if a country has very large, offsetting gross assets and liabilities, but they are denominated in different currencies, then an exchange rate change can have a big effect on net external wealth. When we look at the recent data on capital flows, one striking fact is the phenomenal growth in gross external assets and liabilities. In the last decade especially, gross holdings have risen dramatically in many large economies. Some countries have gross external assets and liabilities that are multiples of GDP (see Lane and Milesi Ferretti 2007). In this case exchange rate changes can be very important. As we noted above, most US liabilities are denominated in dollars (e.g. US Treasury Bills), while most of its assets are denominated in non-dollar investments (e.g. FDI in Europe). In this case, a depreciation of the US dollar increases the dollar value of its assets, while leaving its liabilities unchanged.

In Canada, the breakdown of the gross assets and liabilities into currency composition is not officially reported. But a recent paper by Lane and Shambaugh (2007) has constructed estimates of the currency position of external holdings for a large panel of countries, ending in 2004. They estimate that for 2004, Canada's gross assets are almost all held in foreign currencies, with about 60 percent denominated in US dollars, 14 percent euro, 10 percent in pounds sterling, and the rest in various other currencies. On the other hand, Canada's gross liabilities, according to their estimates, are much more concentrated in Canadian dollars. In their estimate, 55 percent of gross liabilities are in Canadian dollars, 30 percent in US dollars, 8 percent in euro, 3 percent in pounds sterling, and the rest in other currencies.

Recognizing the asymmetry in the currency composition of assets and liabilities, it is clear that movements in Canada's exchange rate will have implications for net foreign assets. In fact, because a lot of our liabilities are in Canadian dollars, but none of our assets are in dollars, an appreciation of the exchange rate will reduce Canadian net foreign wealth. Using Lane and Shambaugh's currency composition estimates for 2004, and assuming they apply equally to 2007, we can estimate impact of the Canadian dollar appreciation of 2007 on net foreign assets. This requires knowledge of a) the gross asset and liability position - here we use the 2006 estimates discussed above, b) the currency compositions described above, and c) the changes in the exchange rate for 2007 - the Canadian dollar appreciated by 20 percent against the US dollar, 7 percent against the euro, 16 percent against the pound, but 


\section{DEVEREUX Much Appreciated? The Rise of the Canadian Dollar}

depreciated by 12 percent against the yen.

Table 1 reports the estimates. Note that this calculation is clearly imperfect, because asset prices themselves changed through the year so as to alter the estimates of assets and liabilities in ways that we are not accounting for here. Nevertheless, the estimates give the pure valuation effect of exchange rate changes themselves, holding other factors constant. The Table indicates that the impact of the dollar appreciation in 2007 reduced Canadian external net wealth by 108 billion dollars. This is a large number-it is equivalent to about 7 percent of Canadian GDP, or alternatively, $\$ 3,600$ per capita. Interestingly, this portfolio impact of the dollar movement is larger than the estimates of any other channels by which the exchange rate appreciation affected the Canadian economy. It is approximately equal to three times the current account surplus of 2006. It is ironic that, probably the largest single impact of the movement in the Canadian dollar in 2007 has gone entirely unreported in the media.

Table 1

\begin{tabular}{|c|c|c|c|c|}
\hline \multicolumn{5}{|c|}{ Gross Assets/GDP = 0.71} \\
\hline $\begin{array}{l}\text { In Canadian Doll } \\
\text { In foreign curren }\end{array}$ & $\begin{array}{l}0.01 \% \\
99.98^{\circ}\end{array}$ & & & \\
\hline of which: & $\begin{array}{c}\text { Euro } \\
15\end{array}$ & $\begin{array}{l}\text { UK } \\
10\end{array}$ & $\begin{array}{l}\text { Yen } \\
4.3\end{array}$ & $\begin{array}{c}\text { Swiss } \\
2\end{array}$ \\
\hline \multicolumn{5}{|c|}{ 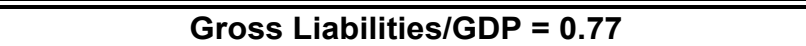 } \\
\hline \multicolumn{5}{|c|}{$\begin{array}{l}\text { In Canadian Dollars 55\% } \\
\text { In foreign currencies } 45 \%\end{array}$} \\
\hline of which: & $\begin{array}{c}\text { Euro } \\
8\end{array}$ & $\begin{array}{l}\text { UK } \\
3\end{array}$ & $\begin{array}{l}\text { Yen } \\
2\end{array}$ & $\begin{array}{c}\text { Swiss } \\
1\end{array}$ \\
\hline \multicolumn{5}{|c|}{ Exchange Rate Change 2007} \\
\hline $\begin{array}{l}\text { US } \\
0.2\end{array}$ & $\begin{array}{l}\text { Euro } \\
0.07\end{array}$ & $\begin{array}{l}\text { UK } \\
0.16\end{array}$ & $\begin{array}{l}\text { Yen } \\
-0.12\end{array}$ & \\
\hline
\end{tabular}

Total Revaluation of Net Foreign Assets = Gross Assets/GDP*(Assets(2007)-Assets(2006))Gross Liabilities/GDP*(Liabilities(2007)-Liabilities(2006))

Source: Cansim, Author's calculations

\section{The Exchange Rate and Canadian Monetary Policy}

We have spent a lot of time discussing the movement of the exchange rate, the theory of real exchange rate determination, and the influence of the exchange rate on the economy. But we have not really touched much on the role of the exchange rate in economic policy, and in particular, the way in which the exchange rate should affect monetary policy. For almost twenty years now, Canada's monetary policy has been directed towards a policy of inflation targeting. This means that the Bank of Canada uses monetary policy primarily to achieve a 
desired target for the rate of inflation. Currently, they target an inflation rate of 2 percent. In practice, this means that the Bank uses its principal monetary policy lever - the short term interest rate - to influence the movement of inflation in the economy. If the inflation rate tends to be above the target rate, the Bank increases the interest rate, while if the inflation rate is below the target, they reduce the interest rate.

Since monetary policy has effectively only one instrument - the short term interest rate, a monetary policy that is used exclusively to target inflation cannot simultaneously be used to achieve a given value for the exchange rate. This means that the Bank of Canada must effectively let the value of the exchange rate be determined freely in the foreign exchange market - Canada has a floating exchange rate system. Almost all advanced economies now have a similar system - they do not try to target their exchange rate. This was not always true. In the immediate post-WWII period, as we discussed in section 2, many countries maintained a fixed value of their exchange rate against the US dollar. And even today, some emerging market economies still intervene in order to prevent their exchange rates from moving - China is the classic example. But a rather different example is the euro area. Before 1999, Europe had many separate currencies - the German d-mark, the French franc, the Italian Lira, for instance. But these countries agreed to form a single currency area, whereby they would use only one currency - the euro, in all countries. This is in effect a radical and permanent form of fixed exchange rate system. Germany and France by definition now have a fixed exchange rate against one another, because they use the same currency.

There is a long and extensive literature in economics on the merits of fixed versus floating exchange rates. After the Second World War, most countries felt that a fixed exchange rate was a necessary requirement of economic stability, and as a result, they formed the Bretton Woods system, fixing against the dollar. But in the last 40 years, the pendulum has swung decisively the other way. Most countries now see the principal role of monetary policy as maintaining low and stable rates of inflation - in effect focusing on internal domestic macroeconomic objectives, and this is inconsistent with keeping the exchange rate fixed.

In the previous discussion, we have touched on some of the arguments for a flexible exchange rate. All economies are vulnerable to macroeconomic shocks from both internal and external sources - Canada for instance is exposed to movements in world oil prices, commodity prices, terms of trade, and US and other country's business cycle fluctuations. The exchange rate can be an important part of the adjustment mechanism to these shocks. For instance, during the Asian crisis of 1997-1998, there was a big fall in the demand for Canadian commodities, because many of the fast growing East Asian economies went into a deep recession. The Canadian dollar fell quite sharply - generating a substantial real exchange rate depreciation, which helped to improve the trade balance and offset the negative effects of the shock on the economy. In this sense, the exchange rate acts as a 'shock absorber', helping to cushion the real economy from the effects of shocks. This type of 


\section{DEVEREUX Much Appreciated? The Rise of the Canadian Dollar}

stabilizing mechanism could not occur with a fixed exchange rate. A second and related argument for flexible exchange rates is the one we already touched on above. If a Central Bank decides to peg its exchange rate to the currency of another currency, then it loses its independence to use monetary policy to guide the economy. So, in response to a negative external shock, the Central Bank could not lower the interest rate to stabilize the economy. It would have to give up its power to influence both the domestic inflation rate and the overall level of economic activity in the economy. The only way that a country can achieve both an independent monetary policy and maintain a fixed value of its currency is if it restricts the free movement of financial capital into and out of the country. This is the way that China currently maintains its fixed exchange rate. But economists agree that free financial flows are a desirable part of the international economic system. Hence, if countries are to have independence in monetary policy, then they must give up control of the exchange rate.

What is the counter-argument for fixed exchange rates? Why do some countries in Asia try to keep their exchange rates pegged? One reason is that exchange rate volatility is perceived to be costly in itself. As we have seen, real and nominal exchange rates are highly volatile, and seem to be only weakly related to economic fundamentals. If we accept this, then it may be harder to make the case that the exchange rate is an efficient macroeconomic adjustment mechanism. Excessive exchange rate volatility may discourage cross-border trade and investment, since firms may have difficulty in planning when future exchange rates are hard to predict. In this view, the exchange rate may be more 'part of the problem' than 'part of the solution', in the sense that exchange rates may exhibit large swings as a result of speculative behaviour in financial markets that has little relationship to current macroeconomic fundamentals. As a result, there may be a case for redirecting monetary policy so as to target the exchange rate, at least partially. In fact, the monetary policy decision is not quite 'black and white', whereby you can either focus on targeting domestic inflation, or targeting the exchange rate, but not both. It is possible to have an intermediate target for the domestic inflation rate, but to adjust monetary policy so as to counter big short term swings in the exchange rate.

If exchange rates tend to overshoot on the way up or down, it may be that monetary policy could be used to prevent this, without giving up on the long run objective of price stability. Devereux and Engel (2009) argue that expectations can be a large determinant of exchange rate swings, and even if these expectations are determined by rational predictions of future fundamentals, there may be a case for monetary policy to partially target exchange rate fluctuations. Whether this applies to Canadian monetary policy however is an open question. We have argued above that commodity and oil prices seem to be an important underlying fundamental driver of the Canadian real exchange rate. In this case, we may argue that movements in the exchange rate are efficient and do not require any compensating action from the Bank of Canada. On the other hand, even if the exchange rate responds in the right 
direction, expectations driven capital flows could lead it to fluctuate too much in response to the underlying fundamentals. The Bank of Canada's exchange rate model does seem to track the actual exchange rate using commodity prices and interest rates as explanatory variables, but there is some overshooting and undershooting according to the model, and even without this, it does not establish that the movement of the exchange rate is fully efficient.

The belief that exchange rate fluctuations are inimical to trade and investment flows in an integrated single market was central to the case for setting up the European single currency. Some economists have argued that a similar set of arguments can be applied to Canada relationship with the US. They argue that a single North American currency would help to integrate Canada into the US market, and prevent the wide swings in real exchange rates that have been a characteristic of the Canadian dollar for the last 15 years. Practically speaking, this would require Canada to adopt the US dollar, since it would be naïve to imagine that the US would give up its own currency so as to enter into a cooperative currency arrangement with Canada.

Would Canada gain from adopting the US dollar? To answer this, we have to consider what is the optimal size of a currency area for North America. The Optimal Currency Area criteria are based on looking at differences in economic shocks among regions, and the ease with which factors of production may move between regions. If two regions are mostly subject to common economic shocks, then there is little need for exchange rate adjustment between the regions, and also the stance of monetary policy should be quite similar in the two regions. In this case, the regions should consider using the same currency, since adopting a common currency brings microeconomic benefits in the form of reducing trade costs and uncertainty between the regions. Even if the regions have differences in shocks, but labour and capital may easily move across regions, then these factor flows act so as to stabilize economic activity between the regions, and they may use a common currency.

Is Canada in an optimal currency area with the US? Most evidence suggests that the answer is no. The Canadian business cycle is similar to that of the US, but the two countries have quite different economic structures, which means that even the same shock, such as a rise in oil prices, have quite different impacts on the two economies. Figure 12 illustrates the movement of Canadian and US GDP growth over the last twenty years. It is apparent that while the two economies move together on average, there have been times when they diverged sharply. This suggests that they do not at the moment form an optimal currency area.

Interestingly, however, the same type of measures for Europe before the inception of the euro area suggested that the European Economies did not form an optimal currency area either. Nevertheless they formed the euro area. The record so far with the euro area suggests that these economies have not suffered from greater regional economic instability by not having an independent exchange rate to adjust to regional shocks. 
Figure 12: Comovement of Growth Rates: US-Canada

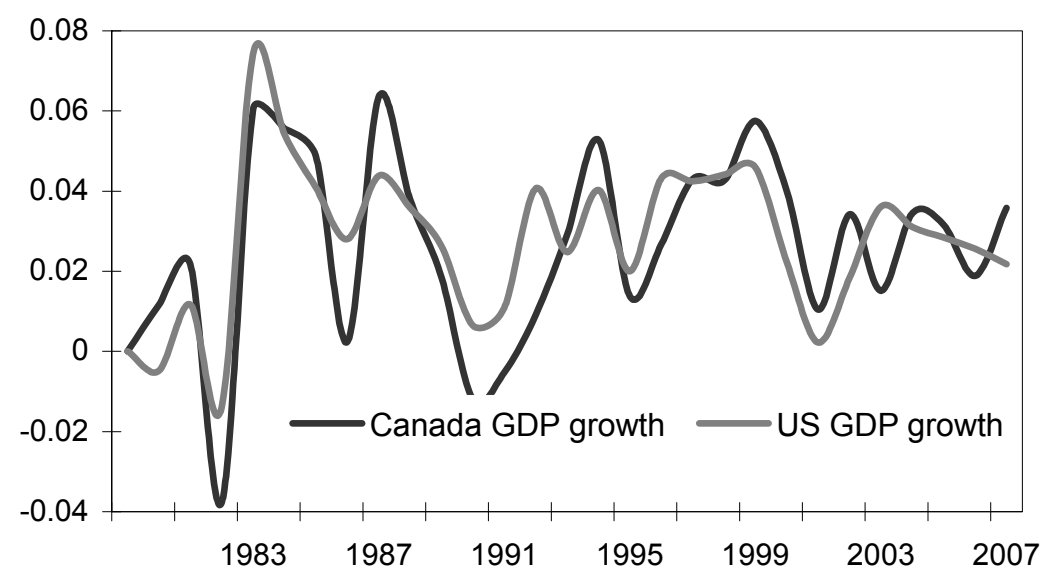

Source: IFS

Some economists have suggested that the formation of a currency area may actually lay the foundation for endogenous economic integration, thereby reducing the costs of giving up on the exchange rate as an adjustment device. Indeed, a related argument applies to Canada itself. The shocks hitting Eastern, Central, and Western Canada have rarely been fully synchronized.

Figure 13: Comovement of Growth Rates: Eastern and Western Canada

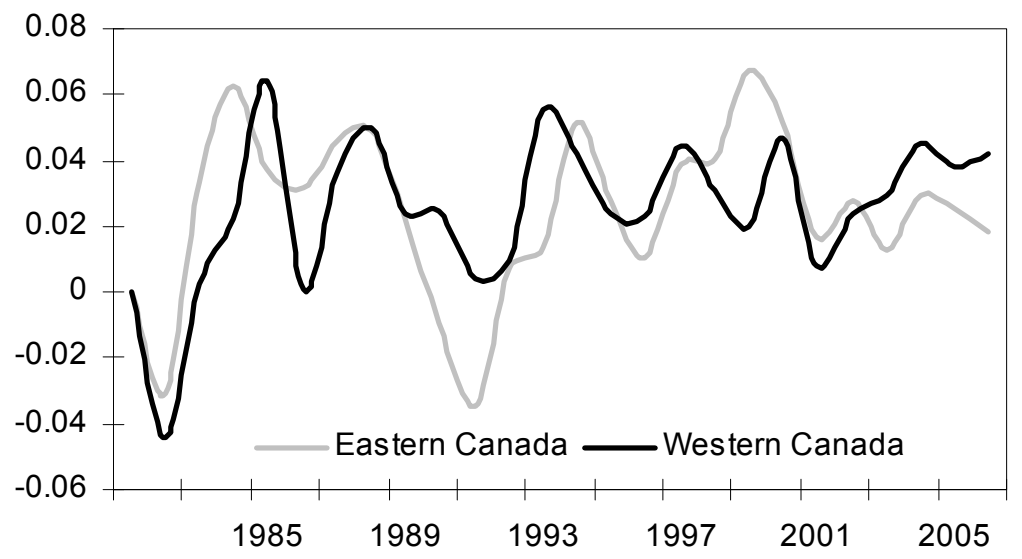

Source: Cansim

Figure 13 shows the size-weighted growth rates of Eastern Canada (Quebec and Ontario), compared with Western Canada (BC Alberta and Saskatchewan). As we see, although there 
is clearly a common Canadian business cycle, in many historical instances, growth rates have been high in Ontario and Quebec, but low or negative in the West, and vice versa. In fact, it could be argued that there is at least as much common co-movement between the US and Canada as between Eastern Canada and Western Canada! Based on the standard optimal currency area criteria, this might suggest that Canada itself is not an optimal currency area. But few economists would suggest that Canada needs two central banks and two currencies. On the whole, the whole country performs very well with a single currency. This suggests that the simple application of optimal currency area criteria are not always relevant. Thus, it is not infeasible that at some time in the future there will be greater consensus for some type of North American single currency arrangement. Until then however, we will have to deal with our dollar ourselves.

\section{Conclusion}

This paper has discussed the recent trend in the Canadian dollar using the backdrop of the academic literature on theoretical and empirical models of exchange rates. From the perspective of theory and empirical evidence, we have argued there are solid underlying reasons for the remarkable real exchange rate appreciation that the Canadian dollar has experienced against the US dollar over the past 5 years. Despite this, it would be naïve to conclude that foreign exchange markets always operate efficiently, and that the value of the dollar always accurately reflects underlying economic fundamentals. As regards the implications for monetary policy however, it is hard to make a case that a more aggressive monetary rule that targeted the nominal exchange rate would have improved Canada's macro performance over the last decade.

\section{References}

Amano, R. and van Norden, S. (1993), A Forecasting Equation for the Canada-US Dollar Exchange Rate, in The Exchange Rate and the Economy, Bank of Canada.

Bachetta, P. and E. Van Wincoop, (2004), A Scapegoat Model of Exchange Rate Fluctuations, The American Economic Review, 94, 114-118.

Bordo, M. A. Dib, and L. Schembri, (2007), Canada's Pioneering Experience With a Flexible Exchange Rate in the 1950s: (Hard) Lessons Learned for Monetary Policy in a Small Open Economy, NBER WP13605.

Bils, M. and P. Klenow, (2004), Some Evidence on the Importance of Sticky Prices, The Journal of Political Economy, 112, 947-985.

Caballero, R. and G. Lorenzoni (2007), Persistent Appreciations and Overshooting: A Normative Analysis, mimeo, MIT.

Chen, Y.C. and K. Rogoff (2003), Commodity Currencies, Journal of International Economics, 60, 133-160. 
DEVEREUX Much Appreciated? The Rise of the Canadian Dollar

Devereux, M. B. and C. Engel, (2009), Expectations, Monetary Policy, and the Misalignment of Traded Goods Prices, NBER International Seminar on Macroeconomics, University of Chicago Press.

Engel, C. (1999), Accounting for US Real Exchange Rate Changes, The Journal of Political Economy, 107, 507-538.

Engel, C. and J. Rogers, (1996), How Wide is the Border?, The American Economic Review, 86, 1112-1125.

Engel, C., N. C. Mark, and K. D. West, (2008), Exchange Rate Models are Not as Bad as You Think, NBER Macroeconomics Annual 2007, University of Chicago Press.

Gourinchas, P.O. and H. Rey, (2007), International Financial Adjustment, The Journal of Political Economy, 115, 665-703.

Lane, P. and G.M. Milesi-Ferretti (2007), The External Wealth of Nations, Mark II, Journal of International Economics, 73, 223-250.

Lane, P. and J. Shambaugh, (2007), Financial Exchange Rates and International Currency Exposures, mimeo. Trinity College Dublin.

Meese, R.A., and K. Rogoff, (1983), Empirical Exchange Rate Models Of The Seventies. Do They Fit out of Sample?, Journal of International Economics, 14, 3-24.

Maier, P. and B. DePratto, (2008), The Canadian Dollar and Commodity Prices: Has the Relationship Changed over Time?, Bank of Canada Discussion Paper 2008-15.

Mark, N. C. (1995), Exchange Rates and Fundamentals: Evidence on Long-Horizon Predictability, The American Economic Review, 85, 201-218.

Mussa, M. (1986), Nominal Exchange Rate Regimes and the Behavior of Real Exchange Rates: Evidence and Implications, Carnegie-Rochester Conference Series on Public Policy, 25, 117-214.

Obstfeld, M. and K. Rogoff (2005), The Unsustainable U.S. Current Account Position Revisited, CEPR Discussion Paper No. 5416.

Rogoff, K. (1996), The Purchasing Power Parity Puzzle, Journal of Economic Literature, 34, 647-668.

Tille, C. (2005), Financial Integration and the Wealth Effect of Exchange Rate Fluctuations,, mimeo, Federal Reserve Bank of New York. 